\title{
The Ninth Annual Southwest Labor Studies Conference, San Jose State University Student Union, April 29-30, 1983
}

\author{
John Laslett \\ Kenneth Pratt
}

University of California, Los Angeles

This was another successful conference, drawing around eighty registrants. Panels were also open to students from San Jose State. There were a number of labor history sessions, including one on California radicalism between the wars in which Ralph Shaffer described the role of Christian socialist Rev. Robert Whitaker. and Kenneth Kahn reported on a commune of radical Jewish chicken ranchers in Petaluma, California. (Who said there were no Jewish farmers?) Margo McBane, Judith Lucero, and Celia Yanish gave papers on women's work in World Wars One and Two, and a largely Mexican-American panel spoke on the history of the New Almaden copper mine over the years. Both of these panels included both academic experts and working men and women. which created a fruitful interchange.

Of the fifteen conference sessions, in fact, at least eight were conducted by trade unionists and community activists, which we as academics found most profitablea valuable corrective to the abstract material we peddle in the classroom-although it was a pity not more of them had a mix of both activists and historians. We also felt that fifteen sessions in less than two days, with four of them running concurrently at one point, were too many for a small conference. The overall theme was organizing in the 'Brave New Workplace.' Six or more sessions dealt with this theme, and the tale they told of unions on the defensive, automation and plant closures adding to unemployment, and employers pursuing open-shop campaigns, was a depressing one. U.A.W. representatives described the effect on jobs of Japanese car manufacturers opening assembly plants in non-union states: Bill Freitas of the I.L.W.U. displayed cassettes and literature being distributed by empoyers to establish a 'union-free environment'; Jim Hirsch of the Carpenters spoke on the effect of the 'two-gate system' on building sites in undermining secondary boycotts: and other union representatives described the export of skilled jobs to Hong Kong by the Atari games manufacturer in 'Silicon valley.' Cesar Chavez also addressed the conference on the problems of the United Farm Workers resulting from conservative 
Governor Deukmajian's hostility towards the Agriculture Labor Relations Board. In view of the cutbacks now being made at every level of California's higher education system, perhaps one of the unspoken lessons of the conference was that academics and working people should draw closer together. This is a stated purpose of the Southwest Labor Studies Association, but one which is rarely realised. Perhaps adversity can help. 